\title{
A Research on the Art Needs of Music Teacher Candidates
}

\author{
Taner Uluçay
}

Faculty of Education Fine Arts Education, Erzincan Binali Yıldırım Univercity, Turkey

Copyright $(2019$ by authors, all rights reserved. Authors agree that this article remains permanently open access under the terms of the Creative Commons Attribution License 4.0 International License

\begin{abstract}
This study aims to determine the art need levels of music teacher candidates with regards to sex and grade level variables. The data of the research were obtained from 102 music teacher candidates studying in the Department of Music Education at Erzincan Binali Y1ldırım University, Faculty of Education. Descriptive screening method was used in this study. The data was gathered through a 'Scale of Need for Art Education' developed by Taşkesen (2014). The data were analysed by using SPSS Statistics 22 Programme and shown in tables. The data findings given in the tables were commented fastidiously. As a result of the study, no significant difference was found between the scores of need for art education with regards to students' grade levels. As well, there was no significant difference between the scores of the need for art education with regards to sex despite the fact that the number of female students was higher than the number of male students.
\end{abstract}

Keywords Music Teacher Candidate, Art Need Level, Department of Music Education

\section{Introduction}

The concept of art is a die-hard matter of fact in a music educator's life and makes the educator feel ill at ease when he/she feels the void of it. In order for the individual to experience the art concept in his/her life, it is necessary for him/her to have a regular, systematic and continuous art education and to feel the concept of art as a need.

According to Uçan (2007: 16) art education is a process that either causes people to gain certain artistic behaviours by means of their own lives, or to change, transform, develop and enhance these artistic behaviours of people through their lives purposefully and methodically.

Art education is an essential educational phenomenon which is believed to be a part of the whole education process beginning from the preschool to undergraduate education. The processes of art education are educational structures connected with each other at the point that they are educational tools and educational subjects. The lack of art education that may occur at any stage of the development process may adversely affect the psychological and physical development of the individual (Uluçay, 2012: 30).

It is expected that communication, empathy, social interaction, self-confidence, success and love will be more intense in the lives of those who see the concept of art as a need in life. The students will be able to leave the cognitiveweighted school environment and become happier, more self-confident and have a high-level of communication in the affective and dynamic educational atmosphere thanks to the art education-based courses.

When we take the fact into consideration that students see the teachers as role models, it becomes more important for teachers to lead and guide their students with their knowledge, skills and abilities. The competencies of the teachers have an effect on student orientation especially in the fields such as painting, music and physical education. However, communication skills, teamwork, social competence and critical thinking have become a necessity no matter what the subject field is. In this way, the student, equipped with the necessary competencies for professional and individual development, could easily reach the full well-being and thus the academic success could develop spontaneously (Herdem Özçelik: 2018).

In addition to giving certain artistic talents to students, art education can also help students in different fields of education and contribute to many of their skills such as problem solving, language development, reading, numerical calculations, recall level and etc.

Thanks to the artistic activities, the students become able to produce and use the acceptable problem solving strategies. Moreover, they can see and perceive their environment and world in a multifaceted interaction, as well (Uzman, Temiz, 2007: 89-90).

As parts of a whole, science and art concepts aim to make sense of the life. The basic aim is to understand the life, human and nature. At the same time, the art of music is regarded as a branch of science thanks to the knowledge 
and methods it involves. On the other hand, it deals with both facts and images (Uluçay, 2012: 34).

Another component that can help the music teacher candidate to be able to express the art concept is his/her musical instrument and now therefore the place and importance of it in his/her life. The teacher candidate could experience the most intense way of art within the moments $\mathrm{s} /$ he spends with his/her instrument. For the candidates who have high motivation towards their instruments, it will be easier to reflect their knowledge and skills to their professional lives (Herdem Özçelik: 2018).

Through art education, it is aimed to educate the students as individuals that finally can gain the ability to express themselves within artistic ways, take responsibility to recognize, to learn about, to protect and hand down their own culture to next generations, and obtain advanced virtual perception. It is also intended to make them as individuals who are respectful to the world cultural heritage, and can become creative and imaginative adults. In order to achieve these goals, it is important to integrate art education into all levels of education most properly and without any interruption. Especially today in which technology rapidly develops and mechanization brings out some problems it is necessary to prepare children to be able to express themselves in different artistic ways for a blessed and productive generation (Buyurgan-Buyurgan, 2007).

The educator acts as a bridge in the development of an individual who is in need of development and has the essential ability and skills to develop. Qualifications and competencies of the educator are of great importance in carrying the potentials of the individuals to higher orders and in making them use their potential for the benefit of the society (Herdem Özçelik: 2016).

Art and art education play an important role for children in understanding their inner worlds and reflecting their imagination. The child does not aim performing an art when painting or playing a musical instrument. The important point for him/her is just fun. At this point, the educator should be able to entertain the child in educating and make the child use his/her imagination and get pleasure.

Games are for children. The children do not paint or play any musical instrument for art. Art education for children is an important issue and it is necessary to attach attention on it. As art arises from human spirit, it brings the unknowns of the children into light. Art, in particular, reflects the imagination of children. It gives them selfconfidence. It is expected that the individuals who are actively involved in art education process could have a high level of ability to create and produce.

When, by using his/her previous knowledge and stimulating the self-inner power, an individual creates a unique product, idea or an approach in the fields that $\mathrm{s} / \mathrm{he}$ thinks are problematic or incomplete, and tests, develops and conveys them to others then it becomes creativity (Herdem Özçelik: 2016).
Art education, lack of which can influence the individual development negatively, is an important educational process and should be included in any level of the education system in accordance with the evolving and changing society structure.

\section{Art and Art Education}

Art education is one of the most reliable environments in which the education of creativity is given priority, divergent thinking is developed, and every student is mentored towards his/her personal development and tendencies. Art education whose main aim is to direct the child to seeing, searching, asking, experimenting and finalizing must keep functioning at all levels of education without interruption. (Buyurgan-Buyurgan, quoted from 2007: 5 Uluçay 2012, p.29).

In order for the individual to feel the phenomenon of art, s/he should first learn the basic knowledge, methods and techniques related. This can be managed on condition that the individual undergoes an effective art education process from an early age. By the way, society, family and governmental institutions perform this process all together. Although art may seem to be an emotion-centred structure, it can be said that it is actually a component of sciences that contain a scheme, numbers, knowledge, and discipline.

Art education is an important educational phenomenon which is believed to be a part of the whole education process from pre-school to undergraduate education. Art education processes are educational structures connected with each other at the point that they are all educational tools and educational areas. The lack of art education that may occur at any stage of the individual development process adversely affect the psychological and physical development of the individual (Uluçay 2012 p. 30).

Art education is one of the basic building blocks of the educational system. Art education, which has a selfdiscipline in itself, is required both for being necessary within the educational institution and for the needs of the children to artistic experience. According to Uzman Temiz (2007: 89-90), students become able to produce and use acceptable problem solving strategies through artistic activities. They can also see and perceive the environment and outer world within multi-dimensional interactions through art education. Thus, the individual that can make sense of what $\mathrm{s} / \mathrm{he}$ sees and experiences can easily evaluate the realities of the era (Uluçay 2012 p.31).

Art education is not an aim but a tool that enables people to perceive the world and people correctly and to discover the features that they possess. It is thought that art education is not a special concept just for certain people but is necessary to be in the educational life of each individual.

\section{Related Research}

This chapter provides information on studies that are 
directly or indirectly related to the research.

In the study 'The Necessity of Art Education for Individual and Society' carried out by Mercin-Alakuş (2007), it is aimed to find an answer to the question "Why is art education necessary for the individual and society?" Previous studies about the field were compiled and personal artistic experiences of the authors were included in the present study. As a result, it is concluded that art education should be included in any phase of the individual's educational life starting from pre-school.

The study "Effects of the Art Education Courses on Creativity Given in Primary Education" conducted by Uysal (2005 puts the emphasis on the fact that in order for creativity to develop, there must be a continuous art education process. Primary school children were examined in the study and solutions for the problems about art education process were discussed.

In the study "Art Education and the Creativity Levels of the Students" carried out by Dikici (2006), the creativity levels of the high school senior students were measured. As a result of the research, the creativity levels of the students who had received art education were found higher than of those who had not received any art education. In addition, the results were analyzed with regards to the gender variable but no significant difference was found between the groups.

Ayaydin (2011) mentions in the study "Art and Painting as a Game in Child Development" that the concept of art entered the life of the child as a game. It was also expressed that self-confidence, self-expression, socialization and emancipation feelings of the child would develop thanks to games through art.

In the study "Human and Motivation of Creating in the Context of Art Creativity”, Ağluç (2013) stated the fact that art and creativity are concepts that are present in the nature of every human-being and every individual can become an artist provided that the required conditions are ensured.

\section{Method}

\subsection{Research Question}

Is there any significant difference between the levels of the need for art education with regards to the grade level and sex variables of the music teacher candidates studying in the Department of Music Education at Erzincan Binali Yıldırım University?

\subsection{Sub-Questions}

1. Is there any significant difference between the levels of need for art with regards to the grade levels of the candidates?

2. Is there any significant difference between the levels of need for art with regards to the sexes of the candidates?

\subsection{Aim}

The aim of this study is to determine the art need levels of music teacher candidates with regards to different variables.

\subsection{Method}

\subsubsection{Research Pattern}

In this study it was aimed to determine the art need levels of music teacher candidates and relational screening method was applied.

\subsubsection{Research Sample}

The sample of the research consists of 84 undergraduate students studying in the Department of Music Education at Erzincan Binali Yıldırım University. Research data were obtained through the application of data collection tools. The frequency and percentage distributions of the students with regards to grade level and sex variables are shown in the tables below.

Table 1. Frequency and Percentage Distribution According to Grade Levels

\begin{tabular}{|c|c|c|}
\hline Grade Level & $\mathrm{f}$ & $\%$ \\
\hline 1 & 21 & 25 \\
\hline 2 & 21 & 25 \\
\hline 3 & 21 & 25 \\
\hline 4 & 21 & 25 \\
\hline Total & 84 & 100,0 \\
\hline
\end{tabular}

Table 2. Frequency and Percentage Distribution According to Sex

\begin{tabular}{|c|c|c|}
\hline Sex & f & $\%$ \\
\hline Female & 39 & 46,4 \\
\hline Male & 45 & 53,6 \\
\hline Total & 84 & 100,0 \\
\hline
\end{tabular}

\subsection{Data Collection Tool}

\subsubsection{Scale of Need for Art Education}

In this study, the 'Scale of Need for Art Education' developed by Taşkesen (2017) was used as the data collection tool. The scale consists of 20 items and has five likert properties. In order to determine the construct validity of the scale, the factor analysis was performed by the researcher using the varimax transformed principal component analysis method, and the Cronbach Alpha reliability coefficient of the scale has been calculated as .84 (Taşkesen, 2017). As a result of the factor analysis a 2factor structure with an eigen-value of over 4.00 was found which explains the $41 \%$ of total variance. As a result of the confirmatory factor analysis conducted for the purpose of verifying this structure, the fit index values were found as RMSEA $=.052, \mathrm{GFI}=.90, \mathrm{CFI}=.90, \mathrm{AGFI}=.89, \mathrm{NFI}$ $=.89, \mathrm{NNFI}=.90$ and SRMR $=.048$ (Taşkesen, 2017). In 
order to determine the extent to which the research subject overlaps with the scale used in the study, factor analysis was applied to the scale items in the light of the data obtained from the students. Since they did not have a value below 30, the items of the scale were used as were. The Cronbach Alpha coefficient of the scale was found to be 0,820 and the reliability coefficient was .86 .

\subsubsection{Data Analysis}

The statistics related to research variables were tested at the significance level of $p>.05$ using SPSS 22.00 programme. The scores gathered through the 'Scale of Need for Art Education' were calculated and the scale score level was created. The scores were associated with the music teacher candidates' personal statistics, and the levels of the need for art education of the candidates were determined in this wise. The Shapiro-Wilk test was applied to see if the data showed normal distribution. As a result, it was found that the data showed normal distribution (.459). From this point of view, 'One Way Anova' test was applied to answer the research sub-questions.

One-factor (way) variance analysis was applied to test whether the difference between two or more unrelated sample mean is significantly different from zero (Büyüköztürk, 2008: 48).

The reason for applying Anova test rather than any other tests in this study was that the measurement (score) sets were not related to each other. Anova design requires the subjects or participants to be present and measured in only one of two or more experimental conditions (Büyüköztürk, 2008: 49).

\section{Findings}

The statistical analyses and related comments are given in this section.

\section{Sub-Question I.}

Is there any significant difference between the art need levels with regards to the grade levels of the candidates? Anova test was applied to analyze the problem. The following tables show the descriptive statistics and Anova test results.

Table 3. Frequency and Percentage Distribution of Art Need Level According to Grade Level Variable

\begin{tabular}{|c|c|c|c|c|c|c|c|c|}
\hline \multicolumn{9}{|c|}{ Descriptive } \\
\hline \multirow{2}{*}{$\begin{array}{l}\text { Grade } \\
\text { Level }\end{array}$} & \multirow{2}{*}{$\mathrm{N}$} & \multirow{2}{*}{ Mean } & \multirow{2}{*}{ Std. Deviation } & \multirow{2}{*}{ Std. Error } & \multicolumn{2}{|c|}{$95 \%$ Confidence Interval for Mean } & \multirow{2}{*}{ Minimum } & \multirow{2}{*}{ Maximum } \\
\hline & & & & & Lower Bound & Upper Bound & & \\
\hline 1,00 & 21 & 71,0000 & 5,98331 & 1,30567 & 68,2764 & 73,7236 & 58,00 & 84,00 \\
\hline 2,00 & 21 & 70,7619 & 5,94899 & 1,29818 & 68,0540 & 73,4699 & 62,00 & 84,00 \\
\hline 3,00 & 21 & 71,1905 & 8,45943 & 1,84600 & 67,3398 & 75,0412 & 47,00 & 81,00 \\
\hline 4,00 & 21 & 70,3810 & 8,09615 & 1,76672 & 66,6956 & 74,0663 & 49,00 & 82,00 \\
\hline Total & 84 & 70,8333 & 7,09120 & ,77371 & 69,2944 & 72,3722 & 47,00 & 84,00 \\
\hline
\end{tabular}

The table shows the level sequence of the four grades. Grade 3 has the highest score and is followed by grade 1 . Grade 2 has the third place in the sequence and precedes grade 4 . As a result, it can be inferred that grade 4 students has a lower art need level when compared to the other three grades.

Table 4. ANOVA Analysis Results of the Art Need Level related to Grade Level Variable

\begin{tabular}{cccccc}
\hline \multicolumn{9}{c}{ ANOVA } \\
\hline Resource of the Variance & Sum of Squares & sd & Mean Square & F & Sig. \\
\hline Between groups & 4173,667 & 3 & 2,556 &, 049 &, 986 \\
\hline
\end{tabular}

Table 3 shows that there is no significant difference between the art need level scores of the music teacher candidates with regards to the grade level variable $(, 986 \mathrm{p}<.05)$.

\section{Sub-Question II.}

Is there any significant difference between the art need levels with regards to the sexes of the candidates? Anova test was applied to analyze the problem. The following tables show the descriptive statistics and Anova test results. 
Table 5. Frequency and Percentage Distribution of Art Need Level According to Sex Variable

\begin{tabular}{|c|c|c|c|c|c|c|c|c|}
\hline \multicolumn{9}{|c|}{ Descriptives } \\
\hline \multirow{2}{*}{ Sex } & \multirow{2}{*}{$\mathrm{N}$} & \multirow{2}{*}{ Mean } & \multirow{2}{*}{ Std. Deviation } & \multirow{2}{*}{ Std. Error } & \multicolumn{2}{|c|}{$95 \%$ Confidence Interval for Mean } & \multirow{2}{*}{ Minimum } & \multirow{2}{*}{ Maximum } \\
\hline & & & & & Lower Bound & Upper Bound & & \\
\hline 1,00 & 39 & 70,1026 & 8,14279 & 1,30389 & 67,4630 & 72,7422 & 47,00 & 82,00 \\
\hline 2,00 & 45 & 71,4667 & 6,05880 & ,90319 & 69,6464 & 73,2869 & 58,00 & 84,00 \\
\hline Total & 84 & 70,8333 & 7,09120 & ,77371 & 69,2944 & 72,3722 & 47,00 & 84,00 \\
\hline
\end{tabular}

Table 5 shows that the number of the male participants is higher than the number of the female participants $(\mathrm{N}=39$ $<45$ ) and, although it is not meaningful, the level of art needs of male participants is higher than female participants $(70,1026<71,4667)$.

Table 6. ANOVA Analysis Results of the Art Need Level related to Sex Variable

\begin{tabular}{cccccc}
\hline & & ANOVA & & Mean Square & F \\
\hline Resource of the Variance & Sum of the Squares & df & 1 & 38,877 &, 771 \\
\hline Between groups & 38,877 & Sig. & 382 \\
\hline
\end{tabular}

Table 5 shows that there is no significant difference between the art need level scores of the music teacher candidates with regards to the sex variable $(, 382 \mathrm{p}<.05)$.

\section{Discussion and Conclusions}

According to the results of the research, it was observed that there was no significant difference between the art need scores of the candidates with regards to their grade levels. Despite the fact that there was no significant difference between the scores, it was found that the art need scores of the 3rd grade students were higher than the other grades while the scores of the 4 th grades were the lowest of all. It can be concluded that amongst all of the music teacher candidates the 4 th grades have the lowest level of art education need.

The results of the tests show that there was no significant difference between male and female participants with regards to sex variable. The number of male participants is higher than that of female participants, and thus the results show that the art need levels of the male participants is higher than that of the female participants.

According to the results of the study, it was seen that both sex and grade level variables do not have a significant effect on the art need levels of the music teacher candidates. This study can also be conducted to other music teacher candidates studying in other universities in Turkey. Studies with different variables can result in different outcomes. The students who take professional music education at different ages can also be included in such a study. It was found that the art need levels of the male participants were higher than that of the female participants. As a result, certain educational studies can be carried out to enable the male students to experience the concept of art more intensively.

\section{REFERENCES}

[1] AĞLUÇ, L. (2013), Sanat Yaratıcılık Bağlamında İnsan ve Yaratma Güdüsü, Mediterranean Journal of Humanities, mjh.akdeniz.edu.tr, III/1, 2013, 1-14 ANTALYA.

[2] ATAN, Ali, (2009). Çocukta Sanat Eğitiminin Önemi, Akademik Yazılar Bülten/1163.

[3] BUYURGAN, Serap, KUMRAL, Çiçek, (2007), Bireyin Eğitim Sürecinde Sanat Eğitimi Neden Yer Almalıdır, 3. Ulusal Sanat Ĕ̆itimi Sempozyumu, 19 - 21 Kasım, Gazi Eğitim Fakültesi, Ankara.

[4] BÜYÜKÖZTÜRK, Şener, (2008), Sosyal Bilimler İçin Veri Analizi El Kitabı, (9. Baskı), Pegem Akademi Yayınları, Ankara, (1. Bask1 2002).

[5] DİKİCİ, A. (2006), Sanat Eğitimi ve Öğrencilerin Yaratıcılık Düzeyleri, Eğitim ve Bilim Dergisi, Cilt:31, Sayı: 139 S: 39, ANKARA.

[6] MERCiN, E. Alakuş, A. ( 2007), Birey ve Toplum için Sanat Eğitiminin Gerekliliği, D.Ü.Ziya Gökalp Eğitim Fakültesi Dergisi Say1:9, S:14-20, DIYYARBAKIR.

[7] ÖZÇELİK HERDEM D., (2018), Güzel Sanatlar Bölümü ile Diğer Bölüm Öğrencilerinin Benlik Saygılarının Karşılaştırılması "Gazi Üniversitesi Eğitim Fakültesi Örneği", Abant İzzet Baysal Üniversitesi Dergisi, Cilt:10, Say1:2 BOLU

[8] ÖZÇELİK HERDEM D., (2018), Keman Öğretim sürecinde Kazanılan Bilgi ve Becerilerin Mesleki Yaşamda Kullanımı ile İlgili Öğretim Elemanı Görüşlerinin Değerlendirilmesi, İdil Dil ve Sanat Dergisi, Cilt:7, Say1:51

[9] ÖZÇELIKK HERDEM D., (2016), Etkin - İdeal Keman Eğitimcisi Özelliklerinin Öğretim Elemanı Görüşlerine Göre Değerlendirilmesi "Müzik Öğretmenliği Programı", Sanat Eğitimi Dergisi, Cilt: 4, Sayı: 2 
[10] ÖZÇELIKK HERDEM D., (2016), Sosyal Bilimlerde Stratejik Araştırmalar ''Editör: Dr. Ömer Kürşad TÜFEKCİ ISBN: 978-3-659-95773-4 Öğretim Elemanı ve Öğrenci Görüşlerine Göre Keman Öğretiminde Yaratıcılığı Artırmaya Yönelik Yaklaşımların Değerlendirilmesi ANTALYA (317-330).

[11] TAŞKESEN, O. (2014). Developing Interest In Art Scale and Determining The Relation Between Personality Type of Teacher Candidates and Their Interest In Art, Educational Research and Reviews, V ol. 9 (8), pp. 216-226, www.academicjournals.org/ERR.

[12] UÇAN, Ali, (2007), Okullarda giddet Sorununun Çözümü Sanat Eğitimi. 3. Ulusal Sanat Eğitimi Sempozyumu, 19-21 Kasım, Gazi Eğitim Fakültesi, Ankara.

[13] ULUÇAY, T. (2012). Müzik Eğitiminin Ortaöğretim Öğrencilerinin Şiddet Eğilimlerine Etkisi. İnönü Üniversitesi Eğitim Bilimleri Enstitüsü Yayınlanmamış Doktora Tezi. MALATYA

[14] UYSAL, A. (2005), İlköğretimde Verilen Sanat Eğitimi Derslerinin Yaratıcılığa Etkileri, Gazi Üniversitesi Kırșehir Eğitim Fakültesi Dergisi, Cilt 6, Sayı 1, (2005), 41-47, KIRŞEHİR.

[15] UZMAN, E., TEMIZ, E., (2007), Sanat Eğitiminin Üniversite öğrencilerinin saldırganlık düzeyleri ve kendini ayarlama davranışlarına etkisi, 3. Ulusal Sanat Eğitimi Seтроzуити, 19 - 21 Kasım. Gazi Eğitim Fakültesi, ANKARA. 